\title{
Factores asociados a la infección celular por el virus de la necrosis pancreática infecciosa (IPNV)
}

\author{
Factors associated with cellular infection by the infectious pancreatic necrosis virus (IPNV) \\ C Ortega ${ }^{1,2 *}$, R Enríquez ${ }^{1}$ \\ ${ }^{1}$ Laboratorio de Biotecnología y Patología Acuática, Facultad de Ciencias Veterinarias, \\ Universidad Austral de Chile, Valdivia, Chile. \\ ${ }^{2}$ Centro de Investigación y Estudios Avanzados en Salud Animal, Facultad de Medicina Veterinaria y Zootecnia, \\ Universidad Autónoma del estado de México. Apdo. postal 4-56. Toluca, México.
}

\begin{abstract}
SUMMARY
The infectious pancreatic necrosis virus (IPNV) is one of the main causes of economic losses in salmon farms. Its temporal expression and the characteristics of its components have been described in many studies, however, the role of proteins in viral pathogenesis has not been completely determined. The aim of this review is to detail the processes that allow the establishment of a virus-cell relationship, replication and dissemination of the infection, highlighting the role of the viral components in such mechanisms and the effect of their variability on viral virulence. The molecular mechanisms that characterize Birnaviruses in relation to their replication, translation and maturity are also described. The host response and defense mechanisms against viral infection are mentioned, highlighting the importance of the non-specific immunity through stimulating the synthesis of antiviral proteins via interferon, and the importance of apoptosis as a defense mechanism that can be modulated by the virus' proteins. Also, the role of viral and cell factors on the development of the carrier stage, which is considered one of the most important aspects in the dissemination of IPNV, is described.
\end{abstract}

Palabras clave: IPNV, infección, virus, virulencia.

Key words: IPNV, infection, virus, virulence.

\section{INTRODUCCION}

El virus de la necrosis pancreática infecciosa (IPNV) es el agente etiológico de una enfermedad de distribución mundial que provoca severas pérdidas económicas en varias especies de peces, principalmente en salmónidos jóvenes. Los animales que sobreviven a la enfermedad clínica y los infectados después de los 6 meses de edad se convierten en portadores asintomáticos, representando riesgo a la salmonicultura y el medio ambiente (Wolf 1988, OIE 2005). El desarrollo y resultado final de la infección es influido por factores que dependen del virus y del hospedero, los cuales a su vez son afectados por el ambiente (Rodríguez y col 2003); por consiguiente, para comprender los mecanismos que facilitan el establecimiento y la evolución de la infección es importante considerar no sólo las propiedades del virus, sino también aquellos elementos del hospedero que median la interacción inicial entre virus y célula y que determinan que una infección sea o no sea productiva en especies susceptibles.

La virulencia, que es la habilidad relativa del agente patógeno para causar enfermedad, es una manifestación

Aceptado: 28.11.2006

* Correspondencia:E-mail: orsc@uaemex.mx; cesarortega@uach.cl Fax (63) 221548; Casilla 567, Valdivia, Chile. de la interacción entre los efectos adversos producidos por componentes del virus y los mecanismos de defensa desarrollados por las células para tratar de eliminar la infección; sin embargo, el resultado de tal interacción siempre es determinado por el virus a través de sus factores de virulencia, función que puede ser ejercida por cualquier componente de la partícula viral (Lyles 2000). Las diferencias en el nivel de virulencia observadas entre distintas cepas de IPNV han sido atribuidas a su variación genética (Dobos 1995a), y con la propiedad del virus para modificar las vías de señalización celular a través de las proteínas virales codificadas por su segmento A, capaces de manipular la maquinaria celular para facilitar la síntesis viral y evadir la respuesta de defensa (Hong y col 1999, Larsen y col 2004). En este sentido, las proteínas virales consideradas como los principales factores de virulencia de IPNV son la VP2, componente de la cubierta externa de la cápside viral que participa en el reconocimiento del virus a las células; la proteína VP5 de función no concluyente, dado que se ha observado no ser necesaria para establecer la infección y la multiplicación viral, pero con actividad antiapoptótica que aparentemente no tiene relación en el establecimiento del estado portador. Recientemente, se ha informado que la sobreexpresión de la proteína VP3 induce apoptosis en células de cultivo, pero es difícil de detectar en una infección con partículas virales completas. En cambio, VP4 y VP1 no se han asociado con 
efectos adversos a nivel celular, pero proteínas de actividad similar en otros virus sí se han observado con implicancia en la patogenicidad de las cepas (Lyles 2000, Liu y Vakharia 2004, Nanda y Baron 2006).

Durante el proceso de infección, el hospedero expresa una variada respuesta encaminada a tratar de impedir la infección o diseminación del agente. Para esto, el sistema de defensa inespecífico es el más importante como medida de protección para los peces y, dentro de éste, el sistema interferón (IFN) es una de las primeras líneas de defensa a la infección viral a través de inducir la síntesis de proteínas que tienen actividad antiviral; en el caso de IPNV, la proteína MxI y la proteína kinasa dependiente de RNA doble hebra (PKR) han demostrado tener actividad antiviral (Robertsen 2005). Sin embargo, se ha informado que algunos virus pueden inhibir o modular la respuesta antiviral ejercida por IFN (Lyles 2000, Nanda y Baron 2006), lo cual también es supuesto para IPNV (Rodríguez y col 2003), pero no ha sido evaluado.

IPNV presenta alta variabilidad antigénica y genotípica, características que influyen en la interacción virus-célula, la virulencia y el desarrollo del estado portador; sin embargo, los mecanismos involucrados en dichos procesos no están plenamente determinados (Rodríguez y col 2003). Algunas de las posibles causas de la variabilidad y los mecanismos que facilitan la infección han sido parcialmente determinados en cultivos de células inoculadas con el virus, o bien se han relacionado a partir de procesos observados en modelos de infección con el Avibirnavirus de la bursitis infecciosa (IBDV) de aves (Coulibaly y col 2005, Santi y col 2005a y 2005b). Debido a las diferencias existentes en las características del agente, la fisiología de los animales y las condiciones ambientales en que viven, se hace necesario generar un conocimiento dirigido a identificar estos mecanismos en organismos acuáticos, que permita comprender los procesos celulares involucrados en el desarrollo de la enfermedad y con ello establecer mejores estrategias para su manejo o evitar su ocurrencia. En la presente revisión bibliográfica se hace una aproximación de los mecanismos utilizados por IPNV para establecer una infección y lograr su multiplicación, la participación de las células en estos procesos y los mecanismos de defensa del huésped.

\section{LA NECROSIS PANCREATICA INFECCIOSA}

La necrosis pancreática infecciosa (IPN) es una enfermedad sistémica aguda y contagiosa que afecta a varias especies de salmónidos jóvenes menores a 1.500 grados día; la enfermedad clínica también puede observarse en salmón del Atlántico (Salmo salar) en etapa de postsmolt (Stangelan y col 1996, Roberts y Pearson 2005) y en otras especies de peces (Novoa y col 1995, Chou y col 1999, Rodríguez y col 2003). IPN es la enfermedad de etiología viral de peces de mayor distribución mun- dial (OIE 2005); reconocida como la de mayor impacto en el cultivo de salmónidos en la Unión Europea y Noruega (Roberts y Pearson 2005, Smail y col 2006) y otros países importantes en el cultivo de salmónidos. Oceanía es considerada la única región libre (OIE 2005).

IPNV penetra a través de branquias y la boca, o pasando también por los poros sensoriales del sistema de la línea lateral (Wolf 1988, Novoa y col 1995, Chou y col 1999). La transmisión vertical se ha comprobado en trucha arco iris (Oncorhynchus mykiss) y trucha café (Salmo trutta); en otras especies se han observado casos asociados a ovas o fluidos sexuales infectados, que probablemente correspondan a una infección vertical por contaminación externa (Reno 1999). Se ha propuesto que la infección vertical también esté asociada a la concentración de partículas virales (Rodríguez y col 2003). Después de un periodo de viremia no detectable, aproximadamente al cuarto día postinfección (pi) se observan áreas de necrosis en páncreas exocrino y otros órganos (Reno 1999); no obstante, la distribución viral puede ser variable en los distintos órganos. Eléouet y col (2001) observaron que el virus podría ser encontrado en varios órganos a excepción del páncreas, lo que puede estar asociado a un distinto nivel de tropismo tisular que presenten diferentes aislados virales.

Durante la enfermedad clínica, la mortalidad es inversamente proporcional a la edad de los animales afectados (Wolf 1988). El cuadro clínico más característico se presenta en la trucha arco iris, trucha de arroyo, trucha café, salmón del Atlántico y varias especies de salmón del Pacífico (Roberts y Pearson 2005). En crías que han completado en forma normal la primera alimentación el brote suele ser menos explosivo, pudiendo alcanzar pérdidas del $70 \%$ o más en un periodo de dos meses. Las pérdidas en animales más grandes pueden ser de entre el 10 y 20\% (Roberts y Pearson 2005).

Las lesiones histológicas en crías son indicativas de infección viral aguda, con extensa y progresiva destrucción de células acinares pancreáticas, escaso infiltrado inflamatorio; el tejido endocrino y células adiposas circundantes se presentan normales o con escasa necrosis (McKnight y Roberts 1976, Wolf 1988). En estómago e intestino anterior se producen procesos variables de degeneración y necrosis (Smail y col 2006), desprendimiento de mucosa (enteritis catarral) hacia el lumen intestinal, en donde se pueden observar células epiteliales con citoplasma hialino eosinofílico e hinchadas, con núcleo generalmente fragmentado, formando acúmulos de material basofílico, distribuido en periferia celular, indicativas de un proceso de apoptosis (células McKnight) (McKnight y Roberts 1976). En hígado es posible encontrar áreas de necrosis focal o generalizada, las cuales suelen ser severas en salmón, mientras que en trucha arco iris son más moderadas o poco significativas (Roberts y Pearson 2005). También se observa degeneración y necrosis hematopoyética renal en distinto grado. 
CARACTERISTICAS GENERALES DEL VIRUS DE LA NECROSIS PANCREATICA INFECCIOSA

El virus de la necrosis pancreática infecciosa (IPNV), miembro del género Aquabirnaviridae es el virus prototipo de la familia Birnaviridae (Dobos 1995a). Fue aislado por primera vez en 1957 de la trucha de arroyo (Salvelinus fontinalis) en Norteamérica (Wolf 1988) y ha sido considerado un agente infeccioso de riesgo en el cultivo de salmónidos; sin embargo, también causa enfermedad en otras especies de peces y ha sido aislado de peces, moluscos y crustáceos de agua dulce y salada de varias partes del mundo (Wolf 1988, Reno 1999, OIE 2005).

El genoma de la partícula viral madura consiste de dos segmentos (A y B) de RNA de doble hebra (dsRNA), contenidos dentro de una cápside icosahédrica sin envoltura de $60 \mathrm{~nm}$ de diámetro. El segmento A presenta dos marcos de lectura abiertos (ORF [open reading frame]); en un ORF mayor codifica una poliproteína (pp) precursora de 106-kDa, que es cotraduccionalmente escindida por la proteasa viral (VP4) para generar las proteínas mayores de la cápside: pVP2, VP3 y la propia VP4 (Duncan y col 1987). Durante la maduración viral, la pVP2 de 62-kDa es escindida a VP2 (54 kDa) (Villanueva y col 2004, Song y col 2005), que en esta forma es la principal proteína de la cápside viral, a la cual se dirigen los anticuerpos neutralizantes tipo específicos, y también actúa como la proteína de unión a las células (Granzow y col 1997). VP3 es una proteína interna de la cápside y es actor fundamental del ensamblaje de la partícula viral; su extremo C-terminal, rico en aminoácidos básicos, se une al RNA viral formando la estructura core de ribonucleoproteína (Maraver y col 2003). El ORF menor del segmento A, precede al ORF mayor y lo solapa parcialmente en su extremo aminoterminal, codifica una proteína no estructural de $17 \mathrm{kDa}$, rica en arginina conocida como VP5 (Santi y col 2005a). Esta proteína de función poco clara es detectada sólo en células infectadas y es sintetizada en pequeña cantidad en la fase inicial de la multiplicación viral (Dobos 1995a).

El segmento B de IPNV codifica sólo una proteína de $94 \mathrm{kDa}$, conocida como VP1, que en el virión se encuentra en forma de polipéptido libre o covalentemente unida al extremo 5' de ambos segmentos del RNA genómico (VPg) (Song y col 2005); actúa como RNA polimerasa dependiente de RNA (RdRp), con función de partidor y polimerasa para la trascripción o síntesis de mRNA y para la multiplicación, participando también en el ensamblaje de la partícula viral (Maraver y col 2003).

\section{LA RELACION VIRUS-CELULA}

Adhesión viral. En células susceptibles, el virus se adhiere en forma específica e inespecífica a polipéptidos de una masa molecular de 100 a $200 \mathrm{kDa}$ de la membra- na plasmática celular (Dobos 1995a), los cuales podrían actuar como receptores del virus (Kuznar y col 1995). Las partículas virales saturan estos sitios de unión de la membrana después de 2 a 3 horas de incubación a $4^{\circ} \mathrm{C}$ a través de la proteína viral de adhesión VP2 (Dobos 1995a). Esta interacción favorece el ingreso del virus por endocitosis al igual que en otros virus sin envoltura (Granzow y col 1997, Kuznar y col 1995, Imajoh y col 2003). Kuznar y col (1995) calcularon que la membrana de células CHSE-214 (Chinook salmon embryo) presenta sitios de unión que pueden reclutar a 6.000 viriones y que sólo un $25 \%$ de estos sitios hacen unión específica con partículas virales, y luego de 20 a 30 minutos de incubación permiten el ingreso del virus a compartimentos endosómicos para adentrarse al citosol. En este paso, los anticuerpos neutralizantes sólo protegen si están presentes (Park y Reno 2003) en los primeros 20 minutos de la infección, tiempo que tarda el virus en ingresar a la célula (Kuznar y col 1995).

La naturaleza de los receptores de Aquabirnavirus es incierta. Debido a que IPNV y Birnavirus marinos (MABV) afectan a un amplio número de huéspedes, se ha propuesto que estos agentes podrían utilizar receptores celulares de características comunes entre las distintas especies, o bien que estos virus utilicen múltiples receptores para adherirse a la célula (Imajoh y col 2003). Por ejemplo, el virus de la hepatitis $\mathrm{C}$ humana utiliza al menos dos receptores que median su ingreso a los hepatocitos. Imajoh y col (2003) observaron que luego de 30 minutos de absorción los MABV se unen de forma específica a una proteína de aproximadamente $250 \mathrm{kDa}$ presente en células CHSE-214, RSBK-2 (Red sea bream kidney), FHM (Fathead minnow) y EPC (Epithelioma papulosum cyprini). Sin embargo, luego de 30 a $60 \mathrm{mi}-$ nutos pi se observan vesículas con partículas virales en el citoplasma de las células a través de microscopía electrónica, a excepción en células EPC. Lo anterior sugiere que la proteína de $250 \mathrm{kDa}$ identificada es una macromolécula común de la membrana de las células utilizadas, que sería el principal receptor en la adsorción de MABV, pero insuficiente para la penetración en la línea EPC, requiriendo entonces un correceptor que probablemente está presente en las otras tres líneas de células. Este mecanismo se ha observado en la infección por el virus de la inmunodeficiencia humana tipo 1 (HIV-1), que usa antígenos de superficie celular CD4 como sitios de adsorción, utilizando otro receptor para la penetración viral.

Endocitosis viral. La adhesión específica de la partícula viral a los receptores celulares permite su endocitosis. Treinta minutos después de la adsorción, el virus se interna dentro de compartimentos vesiculares endosomales periféricos de pH ácido (Kuznar y col 1995) o vesículas cubiertas por clatrina, y luego el ácido nucleico viral es liberado desde el endosoma al citosol. Algunos 
estudios sugieren que la acidificación gradual del $\mathrm{pH}$ endosomal es necesaria para permitir la entrada y liberación del virus al citoplasma (Kuznar y col 1995). Sin embargo, Cohen (1975), en ensayos de infección, demostró que la RdRp asociada al virión es activa sin ningún pretratamiento proteolítico previo del virus, por lo que no sería necesaria la pérdida del recubrimiento viral para que el virus pueda ingresar y multiplicarse en las células infectadas. Asimismo, Espinoza y Kuznar (1997) observaron que la inhibición de la acidificación endosomal en células CHSE-214 no afecta la multiplicación de IPNV y que, por tanto, el pH endosomal no influye en el proceso de entrada al citoplasma celular. Rodríguez y col (2003) sugieren que el pH ácido endosomal podría tener función dual durante la infección, por un lado induciendo cambios en la estructura del virión (denudamiento) y, por otro, aportar el gradiente de $\mathrm{pH}$ necesario como fuente energética para la translocación viral desde el endosoma o la superficie celular hacia el citosol. Por lo tanto, los resultados contradictorios en torno al papel del $\mathrm{pH}$ endosomal sobre la capacidad de replicación de IPNV sugieren que otros complejos de interacción virus-célula por identificar pueden participar en los eventos tempranos del ciclo de la infección viral (Espinoza y Kuznar 1997).

\section{MULTIPLICACION VIRAL}

A una temperatura de incubación de $20^{\circ}$ a $24^{\circ} \mathrm{C}$, IPNV se multiplica rutinariamente in vitro en varias líneas de células establecidas (Moss y Gravell 1969), con mejores resultados de multiplicación y aislamiento en células BF-2 (Bluegill fry) y CHSE-214 (Rodríguez y col 2003). La multiplicación se realiza en el citoplasma celular; el virus y proteínas nunca ingresan al núcleo celular (Dobos 1995a). A $22^{\circ} \mathrm{C}$ de incubación en 16 a 20 horas postinfección (hpi) ocurre un ciclo simple de multiplicación, manifestando un característico efecto citopático (CPE), asociado a la pérdida de la integridad de células y del tejido, que termina en destrucción celular (Moss y Gravell 1969, Dobos 1977, Kuznar y col 1995, Hjalmarsson y Everitt 1999) y consecuente liberación de las partículas virales en cantidad variable, dependiendo de condiciones de incubación y células utilizadas, $10^{6}$ a $10^{7} \mathrm{PFU} /$ $\mathrm{ml}$ en células RTG-2 (Rainbow trout gonad) o 2-5 $\times 10^{8}$ en cultivos de células CHSE-214 (Dobos 1995a). En volumen, la producción de virus es aproximadamente de 0,1 a $0,2 \mathrm{mg}$ de virus por $10^{9}$ células, correspondiente a 1.000-2.000 partículas virales por célula, cantidad baja en relación a la síntesis de reovirus con $30 \mathrm{mg} / 10^{9}$ células (Dobos 1977).

Los procesos sufridos por los Birnavirus después de la endocitosis y los previos al inicio de la transcripción no son totalmente conocidos. Estudios in vitro demuestran que VP1 actúa como partidor y RdRp para que IPNV realice una transcripción semiconservativa asimétrica, sintetizando un RNA de hebra simple (ssRNA), correspondiente al mRNA viral 24S (Dobos 1995a, Dobos 1995b). Las moléculas precursoras de la transcripción son capaces de alcanzar y activar las partículas virales maduras y los complejos de transcripción a través de la cubierta de la cápside e iniciar la transcripción, sin pretratamiento proteolítico o degradación del virión (Cohen 1975, Espinoza y Kuznar 1997).

La síntesis temporal de IPNV y sus macromoléculas ha sido determinada; no obstante, poco se sabe acerca de las estructuras implicadas en el ensamble y la multiplicación virales (Espinoza y col 2000). Luego de la adsorción, en 2 a 4 hpi se detecta en el medio de cultivo un transcrito intermedio de mRNA viral específico de un coeficiente de sedimentación de 14 a 16S y un ssRNA de $24 \mathrm{~S}$ correspondiente al mRNA; entre 4 a 6 hpi puede identificarse la progenie viral con dsRNA, lo mismo que polipéptidos y proteínas virales en proporciones similares (Dobos 1995a, Espinoza y col 2000). El nivel máximo de síntesis del RNA genómico viral en células infectadas se alcanza entre 8 a 10 hpi, correlacionado con la detección del genoma dsRNA. Después de 14 a 16 hpi la síntesis de RNA viral disminuye.

Durante la multiplicación viral temprana las partículas virales se observan en el citoplasma de células infectadas sin mostrar asociación particular con elementos celulares (Espinoza y col 2000). Investigando la distribución subcelular y temporal de las proteínas VP3 y VP2 en células CHSE-214, Espinoza y col (2000) encontraron que a 6 hpi las proteínas estructurales aparecen distribuidas en el citoplasma con mayor expresión a las 8 hpi. Posteriormente, en la etapa tardía de la infección (10 a 12 hpi) se observan acúmulos de VP2 en localización perinuclear, formando pseudocristales y agregados de estructura tubular, que podrían corresponder a zonas de ensamble de las partículas virales. Estos aglomerados únicamente reaccionaron a anticuerpos anti-VP2, lo que sugiere que podrían estar formados sólo por VP2; no obstante, también es posible que pudiesen ser agregados compuestos de VP2 asociada a VP3 y RNA, y que la negatividad al anticuerpo anti-VP3 se deba a que VP3 esté oculta al anticuerpo entre formas procesadas o no procesadas de VP2 (Espinoza y col 2000). Algunas células también muestran partículas maduras individuales dispersas en el citoplasma, lo que sugiere que los agregados también podrían ser áreas de acumulación y no de ensamble, y que la formación de complejos de VP3-RNA observados entre 8 y 10 hpi podrían corresponder a los inicios de la morfogénesis viral (Hjalmarsson y Everitt 1999). Moss y Gravell (1969) también observaron que en la etapa tardía de la infección los viriones maduros parecen estar asociados a estructuras tubulares delgadas de naturaleza desconocida y diámetro similar a las partículas virales que pudieran corresponder a formas virales aberrantes originadas por errores durante la replicación viral (Dobos y col 1995a; Rodríguez y col 2003). 


\section{TRADUCCION VIRAL}

El mRNA de IPNV carece de estructura CAP en su extremo 5'; el virus utiliza un mecanismo de inicio de la traducción mediado por sitios internos de entrada al ribosoma (IRES) presentes en su extremo 5'-no traducible (5'-UTR) al que VP1 se encuentra unido en forma covalente. En IBDV y otros Birnavirus se sugiere que el inicio de la traducción se favorece porque VPg unido al mRNA interactúa con el factor de inicio de la traducción elF4A y realiza la función que los factores elF4E y elF4G desempeñan en la traducción dependiente de CAP; así VPg une a elF4A al extremo 5' del mRNA viral, posicionándolo en una estructura secundaria del mRNA desenrollado que sirve como plataforma al complejo de preiniciación $43 \mathrm{~S}$ que se une al mRNA, posiblemente por apareamiento de bases entre el sitio de unión putativo del rRNA 18S (una secuencia de consenso de 32 nucleótidos presente en ambos segmentos de IBDV) y su complementaria en la unidad ribosomal 40S (Dobos 1995b).

\section{MADURACION VIRAL}

Durante la multiplicación viral en células RTG-2 se liberan virus completamente ensamblados junto con bajas cantidades de monómeros libres de VP3, heterodímeros VP2-VP3, agregados de pVP2 y RNA asociado a VP3; sin embargo, sólo las partículas virales completas son infecciosas (Villanueva y col 2004), mientras que los complejos VP3-RNA no son infecciosos por carecer de suficiente cantidad de VP1 (Hjalmarsson y Everitt 1999; Espinoza y col 2000).

Villanueva y col (2004) observaron que durante un ciclo simple de infección de IPNV en células CHSE-214 es posible identificar dos tipos de partículas virales diferentes, a pesar de que ambas tienen la típica forma icosahédrica, los dos segmentos de dsRNA y todos los polipéptidos de las proteínas estructurales. A las 8 hpi se detecta la partícula primaria o provirión de $66 \pm 2 \mathrm{~nm}$ de diámetro que corresponde a las formas precursoras inmaduras e incompletamente ensambladas del virus. Esta partícula, carente de capacidad infectiva, es detectada simultáneamente con el RNA de doble hebra y continúa generándose más allá de las 18 hpi; esto sugiere que el ensamble del virus se inicia tan pronto como la replicación del dsRNA comienza en la célula. Luego de 3 a 4 horas (12 hpi) el provirión madura convirtiéndose en virión, compuesto por una cápside de proteínas maduras; esta partícula provista de infectividad reduce su diámetro a $60 \mathrm{~nm}$ como parte de los cambios coordinados para adquirir una forma compacta y la capacidad infectiva.

Desde el punto de vista bioquímico, el provirión presenta una composición de 30\% de VP2 y 27\% de VP3, contra un 35\% de VP2 y 30\% de VP3 del virión maduro; esta maduración que aporta capacidad infecciosa y esta- bilidad al virión es resultado de cortes proteolíticos postensamble de las proteínas precursoras de la cápside (Duncan y col 1987, Dobos 1995a). Los proviriones, compuestos de proteínas virales maduras y precursoras (poliproteína y pVP2) son lábiles a productos de actividad antiproteasa, lo que indica que la maduración proteolítica a través del corte de pVP2 a VP2 por parte de la VP4 NS es necesaria para alcanzar la estabilidad del virión. El radio de las proteínas pVP2/VP2 existentes en la partícula determinan su nivel de maduración (Villanueva y col 2004); sin embargo, en cultivos in vitro principalmente se observa la forma inmadura pVP2, que sugiere que la maduración también podría requerir la acción de proteasas celulares, no sólo participación de VP4 (Dobos 1995a).

La maduración postensamble de pVP2 es un proceso común en la morfogénesis de los Birnaviridae, siendo de gran importancia, ya que la región C-terminal de pVP2 escindida durante la maduración de la cápside se ha implicado en el control de la interacción de las subunidades y la flexibilidad durante el ensamble de las proteínas virales de IBDV. VP2 y VP3 forman parte de la cápside viral, formando las capas externa e interna respectivamente (Maraver y col 2003); en el inicio del ensamblaje de la partícula viral, VP1 forma complejos de unión con VP3 formando el core de ribonucleoproteína, esta interacción es favorecida dado que en su extremo C-terminal VP3 es rica en aminoácidos básicos que muestran gran afinidad por el RNA (Persson y Macdonald 1982).

\section{PATOLOGIA DE IPNV A NIVEL CELULAR}

La patogénesis de la infección con el virus de la necrosis pancreática infecciosa (IPNV) no es bien conocida, y aun cuando los marcadores de virulencia no están plenamente determinados, se ha propuesto que la patogenicidad y virulencia se relaciona con la propiedad del virus para modificar las vías normales de señalización celular (hipótesis de redirección de la señalización) a través de las proteínas virales capaces de desarrollar actividad de proteínas kinasa, que manipulan la maquinaria celular para favorecer la transcripción, traducción y multiplicación virales. Cuando el virión se liga a sus receptores y correceptores en la membrana celular, se desencadena una serie de señales a través de cascadas de fosforilación y defosforilación, ya sea para inhibir la expresión de genes que participan en el mecanismo de defensa celular, como es la vía de interferón (Lyles 2000), o bien para reprimir el mecanismo de muerte celular por apoptosis que permita realizar la multiplicación viral, hasta que finalmente la célula huésped muere, con la consecuente liberación de las partículas virales infecciosas (Hong y col 1999, Hong y Wu 2002).

Efecto de IPNV en la síntesis de DNA y de proteínas celulares. La infección por IPNV disminuye la síntesis de 
DNA y de proteínas celulares. Lothrop y Nicholson (1974) informaron que durante la infección de células RTG-2 con IPNV la inhibición de la síntesis del DNA celular se inicia entre 4 y 5 hpi, alcanzando un $85 \%$ de inhibición entre las 9 y 10 hpi. Al parecer, la inhibición no se debe a la acción de algún componente estructural del virión, siendo necesaria la presencia de virus activo, ya que células permanentemente infectadas con partículas defectivas interferentes (DI) no muestran disminución en la síntesis de DNA. En el mismo estudio también se observó que aun cuando la síntesis puede ser inhibida hasta en un $90 \%$, el DNA no es degradado, por lo que las nuevas cadenas pueden realizar la polimerización, aunque a menor nivel.

El mecanismo propuesto para la inhibición de la polimerización del DNA celular es que durante la infección, IPNV, al igual que los reovirus, disminuye los sitios activos del cromosoma para el inicio de la síntesis de DNA, pero no inhibe a las células iniciadas en la fase $\mathrm{S}$ temprana del ciclo celular, en las cuales la síntesis se realiza normalmente junto con la síntesis del mRNA viral (Dobos 1995a), por lo tanto, la inhibición específica de la síntesis del DNA sólo interfiere el inicio de síntesis en nuevas cadenas (Lothrop y Nicholson 1974).

\section{NECROSIS - APOPTOSIS}

La apoptosis o muerte celular programada es un mecanismo de defensa a favor del huésped, intentando cortar el ciclo de infección y prevenir que las células vecinas se infecten; este proceso puede ser inducido por varios estímulos, incluyendo las infecciones virales. En el caso de IPNV, la apoptosis se ha observado en infecciones in vitro e in vivo tanto en infecciones agudas como también en animales portadores, y en distintos tejidos animales (Imajoh y col 2005, Roberts y Pearson 2005); no obstante, Eléouet y col (2001) observaron que el páncreas, órgano blanco de IPNV, no presenta apoptosis durante un proceso infeccioso. Hong y col (1998) establecen que en la infección de células CHSE-214, el CPE observado inicialmente es ocasionado por un proceso de apoptosis y que la necrosis posterior es consecuencia de un proceso postapoptótico; trabajos posteriores relacionaron el CPE como daño postapoptótico (Santi y col 2005b). Sin embargo, Espinoza y col (2005) demuestran que la necrosis raramente es precedida por apoptosis y que durante el ciclo de infección el porcentaje de células en apoptosis nunca es mayor que el de células necróticas. Es de destacar que células positivas a la presencia de antígeno viral han sido negativas a la manifestación de apoptosis (Eléouet y col 2001, Rønneseth y col 2006, Smail y col 2006), haciéndose necesario profundizar en este tema, tomando en cuenta otras variables, como las diferencias en distintos huéspedes y tipos de tejidos analizados, así como las cepas virales, ya que al parecer la apoptosis no es el principal mecanismo responsable de la muerte celular durante la infección por IPNV (Eléouet y col 2001). Joseph y col (2004) en un modelo de infección in vitro con el virus de la anemia infecciosa del salmón observaron que la presentación de la apoptosis es dependiente de las células utilizadas.

IPNV induce muerte celular por represión del gen del factor de sobrevivencia Mcl-1, miembro de la familia de proteínas intracelulares Bcl-2 que son moléculas pro y antiapoptosis (Hong y col 1998, Hong y col 1999). Se sugiere que las proteínas virales podrían estar relacionadas de forma directa o indirecta en este proceso; sin embargo, el mecanismo responsable aún no es claro (Hong y col 1999). La proteína VP5 de IPNV presenta dominios de homología a las proteínas antiapoptóticas tipo Bcl-2 (vBcl-2s) y podría ser utilizada por el virus como un mecanismo para evadir la respuesta de defensa de la célula huésped sobre todo al inicio de la infección, impidiendo la apoptosis para que las partículas virales maduren y adquieran infectividad, algo que se ha considerado como un factor de virulencia del virus (Santi y col 2004, Santi y col 2005b).

Al parecer en la batalla virus-hospedero, la célula en un intento por contrarrestar al virus responde induciendo apoptosis (Santi y col 2005a). En contraste, el virus tratará de producir la mayor progenie posible liberándola de la célula infectada a través de la lisis celular (Lyles 2000). Por tanto, el resultado de la infección podría depender de la habilidad del hospedero para montar una respuesta apoptótica; esto podría explicar las diferencias de susceptibilidad y manifestaciones en diferentes tejidos, diferencias también observadas en peces de edad diferente. Si la respuesta antiviral (apoptótica) es baja, el virus podrá replicarse en alto porcentaje liberando altos títulos de progenie causando lisis y necrosis final, como suele observarse en casos de IPN aguda con extensas áreas de necrosis pancreática y hepática en crías de salmónidos. Cuando el balance es a favor del hospedero se desarrollará un proceso de apoptosis en la etapa inicial de la infección, limitando la producción y diseminación viral (Rønneseth y col 2006, Smail y col 2006).

\section{FACTORES DE VIRULENCIA}

Existen dos serogrupos de IPNV, el serogrupo A incluye 9 serotipos patogénicos para peces; el serogrupo $\mathbf{B}$ comprende un sólo serotipo, avirulento para peces. Las cepas del serogrupo A presentan variación en su nivel de virulencia; no obstante, la variación también se presenta entre cepas del mismo serotipo (Dobos 1995a). Sano y col (1992) al generar un virus compuesto por cepas virulentas y avirulentas de dos serotipos distintos, observaron que la virulencia de IPNV está asociada al segmento A y no con el segmento B. Sin embargo, se ha demostrado que VP1 del IBDV modula su virulencia in vivo (Liu y Vakharia 2004). 
Las proteínas VP2 y VP5 codificadas por el segmento A se consideran los principales factores de virulencia de IPNV. Santi y col (2004), al desafiar salmones del Atlántico con 9 cepas de IPNV de serotipo Sp, obtuvieron que algunas cepas fueron altamente virulentas, causando mortalidad cercana al 90\%, otras cepas no provocaron signos clínicos; las cepas mostraron alta heterogeneidad de nucleótidos en el ORF de VP5 y en algunos aminoácidos de VP2, considerados claves en la virulencia.

Proteína VP2. Por comparación en la secuencia de aminoácidos (aa) de varios aislados de campo de distinto nivel de mortalidad en crías de salmón del Atlántico se identificaron los motivos putativos implicados en la virulencia de cepas $\mathrm{Sp}$. Las cepas virulentas típicamente codifican una VP5 de $12 \mathrm{kDa}$ y tienen residuos Thr, Ala, Thr/Ala, y Tyr/His en las posiciones 217, 221, 247 y 500 respectivamente, en el gen de VP2 (Santi y col 2004). Song y col (2005) realizando un desafío con varias cepas recombinantes de IPNV determinaron que los residuos 217 y 221 de VP2 son los determinantes de virulencia en cepas $\mathrm{Sp}$, y que bajo ciertas combinaciones presentan variación. Así, los virus que codifican Thr en 217 y Ala en 221 fueron muy virulentos; las cepas que codifican Pro en 217 y Ala en 221 fueron medianamente virulentas, y las cepas que codifican Thr en residuo 221 e indistinto 217 resultaron avirulentas, y descartando también al residuo 247 con Thr/Ala como factor importante en la virulencia. No obstante, cepas escocesas con residuos Pro217 y Ala221 en VP2 presentaron virulencia similar a las cepas con Thr en 217 y Ala en 221 (Smail y col 2006), por lo que en infecciones in vivo factores asociados al huésped, origen y condiciones ambientales podrían influir en la virulencia (Santi y col, 2004).

VP2 es una proteína que escasamente se O-glicosila en al menos tres sitios del tercio central de su región hipervariable. Las evidencias indican que la glicosilación se realiza libremente en el citoplasma y no en el retículo endoplásmico o el complejo de Golgi (Espinoza y col 2000). A este respecto, la virulencia de las distintas cepas y su relación con la glicosilación no se ha definido (Park y Reno 2005).

Proteína VP5. Es una proteína no estructural, su función en la actividad biológica del virus es poco concluyente. Esta proteína se detecta sólo en células infectadas, no es evidente en virus purificado, siendo frecuente la existencia de cepas de campo carentes del codón de inicio de la traducción (Santi y col 2005a). La ausencia de su expresión no influye para establecer el proceso de infección y la multiplicación viral tanto in vitro como in vivo (Santi y col 2005a, Santi y col 2005b).

VP5 contiene dominios homólogos a Bcl-2 y se ha demostrado que su sobreexpresión en células CHSE-214 incrementa la viabilidad celular, por probable efecto antiapoptótico, limitando la expresión de proteínas virales estimuladoras de apoptosis (Hong y Wu 2002, Santi y col 2005b). Al posponer la apoptosis VP5 ejerce efecto positivo de sobrevivencia viral (Hong y Wu 2002), caso probable en cepas de baja virulencia, y por tanto cepas que codifican VP5 truncada serían más virulentas (Santi y col 2005a). Las evidencias no son concluyentes, Santi y col (2005a) al utilizar una cepa VP5 truncada de 12 $\mathrm{kDa}$ (rNVI15), otra cepa de $15 \mathrm{kDa}$ de VP5 (rNVI1515K) y una carente de VP5 (rNVI15- VP5) observaron que las tres cepas desarrollaron alta virulencia, causando mortalidad superior al $80 \%$ en smolts de salmón del Atlántico, concluyendo que VP5 no es un factor de virulencia. En el mismo estudio, las tres cepas no mostraron diferencias en el desarrollaron apoptosis, especulando que en la cepa de $15 \mathrm{kDa}$ la apoptosis pudo deberse a una deleción del dominio homólogo a BH2 de Bcl-2, de función antiapoptótica (Santi y col 2005b). La virulencia de las cepas no ha sido relacionada a grado de apoptosis o necrosis que desarrollen.

Debido a su aparente actividad antiapoptótica, inicialmente se propuso que la expresión de VP5 en cepas de IPNV estaría implicada en desarrollar infecciones persistentes; sin embargo, estudios recientes contradicen tal aseveración. Al comparar cepas de alta virulencia que expresaban VP5 y no expresivas se observó que presentaban mortalidad similar en salmón del Atlántico por un periodo de 32 semanas; un comportamiento similar también se observó entre cepas de baja virulencia que expresaban o no VP5 (Santi y col 2005a).

La variabilidad genética y fenotípica. Las mutaciones pueden considerarse parte de las habilidades de los virus RNA para adaptarse al medio, y también influyen en el reconocimiento de receptores, adhesión y los pasos de ingreso a la célula, el crecimiento viral y el tropismo. Las adaptaciones en virus sin envoltura generalmente ocurren en las proteínas externas de la cápside (VP2); estas alteraciones pueden modificar el tropismo y la patogenicidad dado que usualmente participan en la unión y reconocimiento de proteínas receptoras.

Existen algunos estudios que han determinado que, luego de varios pasajes en células de cultivo, las cepas de IPNV pierden virulencia (Park y Reno 2003 y 2005, Ogut 2004); el mecanismo no ha sido plenamente determinado. Song y col (2005) observaron que esto podría explicarse por la adaptación a una mutación de Ala por Thr en el residuo 221 de la proteína de la cápside VP2, y que al parecer el cambio se debe a la rápida adaptación del virus a las células CHSE-214. Así, el virus rNV115C (VP5-12kDa, Thr217, Thr221), adaptado a cultivos se multiplica más rápido y produce más unidades formadoras de placas (PFU) que la cepa parental rNV115 (VP5-12kDa, Thr217, Ala221); en cambio, después de 9 pasajes en células RTG-2 no se observaron sustituciones en residuos de las proteínas de los segmentos A o B de IPNV recombinante, siendo entonces la 
línea de elección para la propagación viral, por prevenir mutaciones por adaptación celular, al menos a un décimo pasaje. Las diferencias observadas en el nivel de síntesis viral entre células CHSE-214 y RTG-2 podría asociarse al hecho de que los aa en los residuos 217 y 221 de VP2 puedan tener mayor o menor afinidad o adhesión a determinado tipo celular (Song y col 2005), en donde sería pertinente determinar en casos clínicos si determinadas cepas muestran predilección por algún tejido $\mathrm{u}$ órgano, y relacionarlo a su nivel de virulencia.

\section{EL ESTADO PORTADOR}

Durante la infección por IPNV in vivo, algunos peces no desarrollan la enfermedad clínica, pero al igual que los animales que sobreviven al proceso clínico patológico, eliminan el virus por largo tiempo (Wolf 1988) actuando como portadores. Existe poca información acerca de los mecanismos moleculares e inmunológicos involucrados en el establecimiento de dicho proceso (Rodríguez y col 2003, Santi y col 2005a). Una probable explicación es que el alto grado de mutaciones espontáneas que se producen debido a las deficiencias en la corrección de errores por parte de la RNA polimerasa dependiente de RNA (RdRp) durante el crecimiento viral a una alta multiplicidad de infección, ocasiona que el virus se replique como cuasiespecie, generando partículas virales que carecen de parte del genoma de un virus estándar e interfieren con la replicación normal de este último. Estas partículas virales, conocidas como partículas defectivas interferentes (DI), compiten con el virus estándar en el aporte de proteínas virales, de tal manera que el ácido nucleico de las DI dependen del virus estándar para su replicación (Lothrop y Nicholson 1974).

Las mutaciones de la cepa afectan la respuesta inmune favoreciendo la cronicidad de la infección; en cambio, la estabilidad genética es limitante para mantener la enfermedad (Santi y col 2004). En este sentido, la presencia de DI, acumuladas como partículas virales después de pasajes de alta multiplicidad con altos títulos virales, son responsables de desarrollar células con infección permanente (Rodríguez y col 2003). La acción de DI también se ha asociado a mantener células CHSE214 persistentemente infectadas luego de sobrevivir a una infección en fase lítica, produciendo bajas cantidades de virus infeccioso sin CPE. Durante pasajes múltiples en cultivos de células, se ha cuantificado un incremento de 20 veces el radio de DI/PFU, lo cual se relaciona con una reducción en el número de PFU más que a un incremento de las DI (Lothrop y Nicholson 1974). Estas partículas defectivas pueden ser reconocidas como antígenos del virus estándar. Las DI no corresponden a productos estimulados por la acción de interferón; inhiben la replicación de virus homólogos, pero no de virus relacionados. La cepa Jasper es más usada en estudios in vitro por producir menor DI (Dobos 1995a).
Por otra parte, estudios in vitro muestran que células en cultivo pueden infectarse de forma permanente sin mostrar CPE, lo que se ha relacionado con la capacidad del virus para codificar proteínas que retrasan o suprimen la apoptosis o muerte celular, y consecuentemente mantener la sobrevivencia celular, favoreciendo la síntesis de su progenie. El frecuente cambio de Ala por Thr en el residuo 221 en cepas IPNV adaptadas a cultivos celulares ha sido relacionado también como mecanismo molecular del establecimiento del estado portador (Santi y col 2005a). Esto podría ser resultado de distinto nivel de tropismo celular que las cepas virales pueden presentar durante una infección aguda con predilección del residuo Ala221 por el páncreas exocrino, intestino e hígado, o la predilección del virus adaptado o mutado con residuo 221Thr hacia los macrófagos para la infección persistente. En el caso del virus de la hepatitis C, la secuencia de cepas extrahepáticas obtenidas de células dendríticas difiere de la secuencia de las cepas obtenidas de plasma en los mismos pacientes. Existe riesgo de que virus atenuados en peces con infección subclínica puedan reemerger como cepas virulentas ante situaciones de estrés y causar un cuadro clínico de IPN (Wolf 1988, Jarp y col 1996).

Los residuos implicados en la virulencia de VP2 se encuentran en el dominio hipervariable que contiene los principales epítopes reconocidos por los anticuerpos monoclonales; las mutaciones cambian los epítopes de superficie de la cápside viral, ocasionando pérdida de virulencia y establecimiento de infección persistente. Finalmente, Coulibaly y col (2005) al observar la estructura cristalizada de IBDV e IPNV determinan que los residuos 217 y 221 se encuentran inmersos en los "loops" más externos del dominio de proyección $(\mathrm{P})$, donde las mutaciones escapan a la neutralización (Santi y col 2005a).

Otra causa del establecimiento del estado portador es el hecho de que IPNV puede afectar al tejido del sistema inmune y suprimir su respuesta (descrito más adelante). Las células T citotóxicas (CTL) son importantes para controlar infecciones por virus, y el trastorno o inactivación de estas células puede llevar a la persistencia. Los virus RNA tienen una proporción de mutación alta y cuando las mutaciones involucran a cierto péptido viral pueden interferir con el procesamiento del antígeno o en el reconocimiento de los péptidos del complejo principal de histocompatibilidad (MHC) por los receptores de las células T. Otros mecanismos de establecer persistencia puede ser que los mutantes escapen a los anticuerpos y repriman la respuesta del MHC (Robertsen 2005).

\section{MECANISMOS DE DEFENSA}

Los peces responden a infecciones virales a través de inmunidad específica e inespecífica. La primera, se desarrolla semanas después del inicio de la infección y es influida por la temperatura, edad o etapa de desarrollo 
del pez. El sistema innato es una respuesta más rápida, independiente de la temperatura y es el mecanismo de defensa más importante en organismos acuáticos (Robertsen 2005). En salmónidos la respuesta inmune es muy variable, generalmente insuficiente para eliminar la infección por IPNV, pudiéndose desarrollar enfermedad clínica de severidad variable o bien establecerse el estado portador, lo cual depende de factores asociados al propio agente, los peces y el ambiente (Jarp y col 1996).

\section{INMUNIDAD ESPECIFICA}

La respuesta inmune humoral específica contra IPNV se observa cuando peces que reciben suero de animales inmunizados resisten a infección posterior (Jarp y col 1996); asimismo, después de infección in vivo o inmunización con virus inactivo se estimula la producción de anticuerpos neutralizantes específicos tipo IgM contra VP2 y VP3. Sin embargo, existen resultados contradictorios acerca del establecimiento y efectividad de la respuesta de los anticuerpos, los cuales pueden aparecer a la segunda semana pi y tener una duración muy variable. Por una parte, se ha observado disminución viral cuando existen altos títulos de anticuerpos (Jarp y col 1996) y, en cambio, en otros casos altos títulos de anticuerpos no garantizan disminución del título viral. En cualquier caso, la presencia de anticuerpos no es capaz de prevenir el establecimiento de la infección o eliminar el estado portador; además, las respuestas observadas en peces individuales presentan títulos variables (Rodríguez y col 203, Munro y col 2006).

\section{INMUNIDAD INESPECIFICA}

Factores séricos-proteína $6 S$. El pasaje de IPNV en cultivos de células en presencia o ausencia de suero de trucha arco iris (RTS) modifica su nivel de virulencia; sin embargo, los efectos del RTS sobre la virulencia de IPNV in vivo no son concluyentes (Park y Reno 2005). A través de estudios in vitro, se ha considerado que el grado de resistencia a la inhibición viral por RTS podría ser un factor de virulencia en la patogénesis de IPNV (Park y Reno 2003). No obstante, en general se ha observado que la virulencia de la cepa no se correlaciona con el nivel de inhibición, y que la inhibición in vitro e in vivo no dependen del serotipo viral, e inclusive existen diferencias en un mismo serotipo (Ogut 2004). Cepas virulentas Sp de IPNV cultivadas en ausencia de suero se tornan avirulentas, desarrollando sensibilidad a la inactivación. Un resultado contradictorio se obtuvo al cultivar cepas avirulentas en presencia de RTS, incrementando su virulencia (Rodríguez y col 2003); en este caso no se aportaron mayores datos del resultado ni se determinó la secuencia de las proteínas virales que permitirían explicar las razones de las variaciones. En cualquier caso, se sabe que la virulencia de IPNV no es preservada al usar RTS (Ogut 2004).
La inactivación viral por parte del RTS es por acción de una proteína tipo anticuerpo, conocida como $6 \mathrm{~S}$ (por coeficiente de sedimentación 6S), diferente de IgM (coeficiente de sedimentación 14-16S) que no es inducida por interferón o por unión a receptores celulares (Park y Reno 2003). En ensayo in vitro, después de incubar células FHM con IPNV en presencia de 1,3\% de RTS por 20 minutos, aproximadamente $97 \%$ de los virus no fueron adsorbidos; mientras que en ausencia de RTS, $45 \%$ de virus fue adsorbido (Park y Reno 2003). La disminución en la adsorción se debe al bloqueo del virus para ligarse a la superficie celular. El pretratamiento de las células con RTS previo a la exposición de IPNV no afecta la inhibición de IPNV, demostrando que el suero no enmascara al receptor viral.

La inhibición viral es más eficiente cuando el cultivo se realiza en células de salmónidos, mayor en pases múltiples en células RTG-2 que en CHSE-214 (Park y Reno 2005). Es posible que la mutación por múltiples pasajes también influya en el nivel de resistencia al RTS, además de las propias características fenotípicas en cepas como su probable glicosilación. Sin embargo, se ha observado que la sensibilidad puede ocurrir desde el primer pasaje (Park y Reno 2003 y 2005, Ogut 2004), y que varios factores determinen este proceso, sobre todo en condiciones in vivo.

\section{SINTESIS Y ACCION DE INTERFERON}

El interferón (IFN) es una de las primeras líneas de defensa contra algunos virus, es un factor celular inducido apenas después del establecimiento de la infección, antes que aparezca cualquier otro mecanismo de defensa. Las células normales no tienen IFN preformado, ni lo secretan constitutivamente; los inductores de IFN tipo I incluyen la infección de virus RNA de doble hebra, lipopolisacáridos (LPS) y componentes de algunas bacterias (Larsen y col 2004, Robertsen 2005).

El interferón $\alpha / \beta$ o de tipo I es producido por casi todos los tipos celulares, mientras que el IFN- $\gamma$ o tipo II es principalmente producido por los linfocitos T CD4+ helper y CD8+ después de ser estimuladas por células presentadoras de antígenos (Nanda y Baron 2006). El IFN tipo I, tipo II y el factor de necrosis tumoral TNF $\alpha$ tienen capacidad de activar vías intracelulares de señalización que pueden interferir con la multiplicación viral. También reclutan y activan a las células "natural killer" (células NK) capaces de matar y lisar células infectadas por virus, previniendo la multiplicación viral (un mecanismo disminuido en peces en estado portador). Las células bajo influencia de IFN sintetizan proteínas de actividad GTPasa, conocidas como Mx, de las que se han descrito formas nucleares y citoplásmicas que inhiben la multiplicación viral (Haller y col 1998, Larsen y col 2004). IPNV es inhibido en células de salmón que expresan altos niveles de proteína Mx después de 
tratamiento con interferón o poly (I-C) (Jensen y col 2002, Rodríguez y Pérez-Prieto 2006). A pesar de la correlación entre inhibición de IPNV y expresión de proteínas Mx en células tratadas con IFN, el modo de acción no se ha clarificado, se sugiere una interacción directa de las proteínas Mx y los virus diana (Goodbourn y col 2000, Jensen y col 2002, Altmann y col 2003, Caipang y col 2003).

La inyección de IPNV en salmón del Atlántico postsmolt induce rápida expresión del mRNA de la proteína Mx desde el día 1 y hasta los 11 días; esta respuesta no elimina la infección. En contraste, peces mayores portadores de IPNV no expresan transcritos de Mx, lo que hace evidente que esta respuesta depende de la edad de los animales (Lockhart y col 2004); para ello se ha observado que en peces de edad susceptible la expresión de Mx es más aguda, mayor y más prolongada que en no susceptibles, lo que puede explicarse por la síntesis viral y presencia de dsRNA que estimula la síntesis de IFN. Lo mismo también es variable entre especies (Goodbourn y col 2000, Robertsen 2005).

El estado fosforilado del factor de inicio de la traducción, eIF2 $\alpha$ se incrementa en respuesta a la infección por IPNV en células RTG-2, y el grado de fosforilación se correlaciona con la multiplicidad de la infección; lo anterior implica que el sistema de la proteína kinasa dependiente de RNA (PKR), inducido por IFN también está presente en peces, activado por dsRNA (rtPKR). Estos estudios resaltan la respuesta de IFN/ eIF $2 \alpha /$ PKR a la infección viral como un mecanismo primitivo de protección en vertebrados (Goodbourn y col 2000).

Se ha propuesto que la virulencia de distintas cepas virales podría estar asociada a su capacidad de modular o evadir la respuesta antiviral ejercida por IFN. En este sentido, el hecho de que el denudamiento no sea un requisito para la replicación de IPNV podría ser una medida de protección ejercida por el virus para prevenir la inducción de IFN. Asimismo, algunos virus son intrínsecamente resistentes a la acción del IFN porque producen proteínas que enmascaran la forma libre del dsRNA viral, bloquean la activación de PKR y la oligo adenilato sintetasa (2-5 OAS) de modo que no se pueda activar la respuesta antiviral y permiten la producción de virus (Lyles 2000). En otros casos como en el virus de la peste bovina, se inhibe la fosforilación y subsecuente dimerización de los activadores de la transcripción stat 1 y stat 2 , con lo cual se impide su translocación al núcleo, bloqueando la síntesis de IFN tipo I (Nanda y Baron 2006). En el caso de IPNV, si bien es cierto que se ha observado un efecto antiviral por IFN tipo I vía la proteína MxI, no se ha determinado si dicha respuesta se vea modificada por distintas cepas virales y que proteínas virales podrían estar implicadas en ello.

\section{RESPUESTA INESPECIFICA CELULAR E INMUNOSUPRESION}

El conocimiento de la inmunidad celular y su función antiviral es escasa en peces. El sitio exacto de multiplicación de IPNV no se conoce; sin embargo, el hecho de que el aislamiento se realiza preferentemente de riñón anterior y órganos linfoides muestra a un virus leucotrópico, con posibilidad de multiplicarse aunque en forma limitada en distintos tipos de leucocitos, contribuyendo a la inmunosupresión. Luego de la infección intraperitoneal (IP), el virus es transportado por células fagocíticas al riñón, que contribuyen a la distribución viral en truchas portadoras (Rønneseth y col 2006).

IPNV no se multiplica en macrófagos de trucha cultivados in vitro, pero si se observa un ligero incremento del título viral cuando el virus se incuba en leucocitos totales. Linfocitos B, que cuando son estimulados con LPS muestran una clara proliferación, sufren una reducción significativa de esta proliferación cuando son infectados con IPNV, lo que es indicativo del efecto inmunosupresor del virus (Novoa y col 1996). De igual manera, Knott y Munro (1986) observaron que salmones del Atlántico portadores de IPNV tienen deprimida la mitogénesis leucocítica, disminuyendo su acción para eliminar fitohemaglutinina, reduciendo también el número de células citotóxicas naturales (NCC) e incremento del factor inhibidor de la migración de macrófagos. En apoyo a lo anterior, Rønneseth y col (2006) observaron que el nivel de neutrófilos sanguíneos y ranales de salmón del Atlántico parr y postsmolts disminuye luego de un desafío experimental con IPNV; esta última observación es considerada como una de las principales explicaciones de que los peces afectados por esta infección sean propensos a padecer enfermedades bacterianas secundarias.

Sobre la base de observaciones realizadas en IBDV, se ha sugerido que la inmunodepresión y el consecuente establecimiento de estado portador se debe a la capacidad del virus a suprimir linfocitos B. El virus tiene predilección a multiplicarse en células $\mathrm{B}$, causando inmunodepresión por disminución de la expresión de inmunoglobulinas y lisis de células productoras de Igs (Novoa y col 1996, Rønneseth y col 2006).

\section{COMENTARIO FINAL}

El virus de IPN es un patógeno muy importante en la salmonicultura mundial; no obstante, los aspectos asociados al mecanismo de patogénesis no han sido bien determinados aunque algunas de las proteínas virales y su variabilidad genética se han relacionado como factores asociados a su virulencia por una probable capacidad para resistir o evadir los mecanismos de inmunidad. Un mejor conocimiento de estos procesos podría contribuir a comprender la relación virus-célula y la 
patogénesis, lo cual podría ser utilizado en las estrategias para disminuir los efectos económicos y ambientales de la enfermedad.

\section{RESUMEN}

El virus de la necrosis pancreática infecciosa (IPNV) es una de las principales causas de pérdidas económicas en salmónidos de cultivo; la expresión temporal y las características de sus componentes han sido descritas en varios trabajos; sin embargo, el papel de las distintas proteínas en la patogénesis viral no ha sido completamente determinado. En este artículo se presenta una revisión bibliográfica de los procesos que permiten establecer la relación virus-célula, la replicación y diseminación de la infección, destacando el papel de los componentes virales en tales mecanismos y los efectos de su variabilidad sobre la virulencia viral, describiendo también los mecanismos moleculares que son característicos de los Birnavirus en relación a su replicación, traducción y maduración. Las respuestas y mecanismos de defensa del hospedero en contra de la infección viral son abordadas resaltando la importancia de la inmunidad inespecífica a través de la vía interferón como estimulador de la síntesis de proteínas antivirales y la implicancia de la apoptosis también como un mecanismo de defensa, pero que puede ser modulado por las proteínas del virus. El desarrollo del estado portador, considerado uno de los aspectos más importantes en la diseminación de IPNV, se aborda describiendo la participación de factores virales y celulares.

\section{REFERENCIAS}

Altmann SM, MT Mellon, DL Distel, CH Kim. 2003. Molecular and functional analysis of an interferon gene from the zebrafish, Danio rerio. J Virol 77, 1992-2002.

Caipang CM, I Hirono, T Aoki. 2003. In vitro inhibition of fish rhabdoviruses by Japanese flounder, Paralichthys olivaceus Mx. Virology 317, 373-382.

Chou HY, TY Peng, SJ Chang, YL Hsu, JL Wu. 1999. Effect of heavy metal stressors and salinity shock on the susceptibility of grouper (Epinephelus sp.) to infectious pancreatic necrosis virus. Vir Res 63, 121-129.

Cohen J. 1975. Ribonucleic acid polymerase activity in purified infectious pancreatic necrosis virus of trout. Biochem Biophys Res Comm 62, 689-695.

Coulibaly F, C Chevalier, I Gutsche, J Pous, J Navaza, S Bressanelli, B Delmas, FA Rey. 2005. The Birnavirus crystal structure reveals structural relationships among icosahedral viruses. Cell 120, 761772.

Dobos P. 1977. Virus- specific protein synthesis in cells infected by infectious pancreatic necrosis virus. J Virol 21, 242-258.

Dobos P. 1995a. The molecular biology of infectious pancreatic necrosis virus. Annual Rev Fish Dis 5, 25-54.

Dobos P. 1995b. Protein primed RNA synthesis in vitro by the virion associated RNA polymerase of infectious pancreatic necrosis virus. Virol 208, 19-25.

Duncan R, E Nagy, PJ Krell, P Dobos. 1987. Synthesis of infectious pancreatic necrosis virus polyprotein, detection of a virus- encoded protease, and fine structure mapping of genome segment A coding regions. J Virol 61, 3655-3664.

Eléouet JF, N Druesne, S Chilmonczyk, D Momge, M Dorson, B Delmas. 2001. Comparative study of in-situ cell death inducid by the viruses of viral haemorrhagic septicaemia (VHS) and infectious pancreatic necrosis (IPN) in rainbow trout. J Comp Pathol 124, 300-307.

Espinoza JC, J Kuznar. 1997. Infectious pancreatic necrosis virus (IPNV) does not require acid compartments for entry into cells. Arch Virol 142, 2303-2308.
Espinoza JC, A Hjalmarsson, E Everitt, J Kuznar. 2000. Temporal and subcellular localization of infectious pancreatic necrosis virus structural proteins. Arch Virol 145, 739-748.

Espinoza JC, M Cortes, J Kuznar. 2005. Necrosis of infectious pancreatic necrosis virus (IPNV) infected cells rarely is preceded by apoptosis. Virus Res 109, 133-138.

Goodbourn S, L Didcock, RE Randall. 2000. Interferons: cell signalling, immune modulation, antiviral response and virus countermeasures. J Gen Virol 81, 2341-2364.

Granzow H, F Weiland, D Fichtner, PJ Enzmann. 1997. Studies of the ultrastructure and morphogenesis of fish pathogenic viruses grown in cell culture. J Fish Dis 20, 1-10.

Haller O, M Frese, G Kochs. 1998. Mx proteins: mediators of innate resistance to RNA viruses. Rev Sci Technol 17, 220-230.

Hjalmarsson A, E Everitt. 1999. Identification of IPNV- specified components released from productively infected RTG-2 cell following massive cytopathic effect. Arch Virol 144, 1487-1501.

Hong JR, TL Lin, YL Hsu, JL Wu. 1998. Apoptosis precedes necrosis of fish cell line with infectious pancreatic necrosis virus infection. Virol 250, 76-84.

Hong JR, YL Hsu, JL Wu. 1999. Infectious pancreatic necrosis virus induces apoptosis due to down-regulation of survival factor MCL-1 protein expression in a fish cell line. Virus Res 63, 75-83.

Hong JR, TL Lin, YL Hsu, JY Yang, JL Wu. 1999. Dynamics of nontypical apoptotic morphological changes visualized by green fluorescent protein in living cells with infectious pancreatic necrosis virus infection. J Virol 73, 5056-5063.

Hong JR, JL Wu. 2002. Induction of apoptotic death in cells via Bad gene expression by Infectious pancreatic necrosis virus infection. Cell Death Differ 9, 113-124.

Imajoh M, K Yagyu, S Oshima. 2003. Early interaction of marine birnavirus infection in several cell lines. J Gen Virol 84, 18091816.

Imajoh M, T Hirayama, S Oshima. 2005. Frequent occurrence of apoptosis is not associated with pathogenic infectious pancreatic necrosis virus (IPNV) during persistent infection. Fish Shellfish Immunol 18, 163-177.

Jarp J, T Taksdal, B Tørud. 1996. Infectious pancreatic necrosis in Atlantic salmon Salmo salar in relation to specific antibodies, smoltification, and infection with erythrocytic inclusion body syndrome (EIBS). Dis Aquat Org 27, 81-88.

Jensen I, R Larsen, B Robertsen. 2002. An antiviral state induced in Chinook salmon embryo cells (CHSE-214) by transfection with the double-stranded RNA poly I:C. Fish Shellfish Immunol 13, 367-378.

Joseph T, A Cepica, L Brown, BO Ikede, F Kibenge. 2004. Mechanism of cell death during infectious salmon anemia virus infection is cell type-specific. J Gen Virol 85, 3027-3036.

Knott R, A Munro. 1986. The persistence of IPNV in Atlantic salmon. Vet Immunol Immunopathol 12, 359-364.

Kuznar J, M Soler, G Farias, JC Espinoza. 1995. Attachment and entry of infectious pancreatic necrosis virus (IPNV) into CHSE-214 cells. Arch Virol 140, 1833-1840.

Larsen R, TP Røkenes, B Robertsen. 2004. Inhibition of infectious pancreatic necrosis virus replication by Atlantic salmon Mx1 protein. J Virol 78, 7938-7944.

Liu M, VN Vakharia. 2004. VP1 protein of infectious bursal disease virus modulates the virulence in vivo. Virol 330, 62-73.

Lockhart K, SK Gahlawat, D Soto-Mosquera, TJ Borden, AE Ellis. 2004. IPNV carrier Atlantic salmon growers do not express Mx mRNA and poly I:C-induced Mx response does not cure the carrier state. Fish Shellfish Immunol 17, 347-352.

Lothrop D, BL Nicholson. 1974. Inhibition of cellular DNA synthesis in cells infected with infectious pancreatic necrosis virus. $J$ Virol $14,485-492$.

Lyles D. 2000. Cytopathogenesis and inhibition of host gene expression by RNA viruses. Microbiol and Mol Biol Rev 64, 709-724. 
Maraver A, A Oña, F Abaitua, D González, R Clemente, JA RuizDíaz, JR Castón, F Pazos, JF Rodríguez. 2003. The oligomerization domain of VP3, the scaffolding protein of infectious bursal disease virus, plays a critical role in capsid assembly. J Virol 77, 64386449.

McKnight J, RJ Roberts. 1976. The pathology of infectious pancreatic necrosis. I. The sequential histopathology of the naturally occurring condition. Br Vet J 132, 76-85.

Moss LH, M Gravell. 1969. Ultrastructure and sequential development of infectious pancreatic necrosis virus. $J$ Virol 3, 52-58.

Munro ES, SK Gahlawat, F Acosta, AE Ellis. 2006. In infectious pancreatic necrosis virus carrier Atlantic salmon, Salmo salar L., post-smolts, almost all kidney macrophages ex vivo contain a low level of non-replicating virus. J Fish Dis 29, 43-48.

Nanda S, M Baron. 2006. Rinderpest virus blocks type I and type II interferon action: role of structural and nonstructural proteins. J Virol 80, 7555-7568.

Novoa B, JL Barja, A Figueras. 1995. Entry and sequential distribution of an aquatic birnavirus in turbot (Scophthalmus maximus). Aquaculture 131, 1-9.

Novoa B, A Figueras, CJ Secombes. 1996. Effects of in vitro addition of infectious pancreatic necrosis virus (IPNV) on rainbow trout Oncorhynchus mykiss leucocyte responses. Vet Immunol Immunopathol 51, 365-376.

Ogut H. 2004. Effects of rainbow trout (Oncorhynchus mykiss) serum (RTS) on replication of infectious pancreatic necrosis virus (IPNV). Turk J Vet Anim Sci 29, 505-510.

OIE, Oficina Internacional de Epizootias. 2005. Aquatic Animal Health Code $\left(8^{\text {th }}\right.$ ed). Paris, France.

Park KC, PW Reno. 2003. The effect of in vitro passage of infectious pancreatic necrosis virus (IPNV) on virulence and sensitivity of the virus to rainbow trout serum. J Aquat Anim Health 15, 128-135.

Park KC, PW Reno. 2005. Characteristics of inhibition of infectious pancreatic necrosis virus (IPNV) by normal rainbow trout Oncorhynchus mykiss serum. Dis Aquat Org 63, 43-52.

Persson H, RD Macdonald. 1982. Evidence that infectious pancreatic necrosis virus has a genome-linked protein. $J$ Virol 44, 437-443.

Reno PW. 1999. Infectious pancreatic necrosis virus and associated aquatic Birnaviruses. En "Fish Diseases and Disorders": Viral, bacterial and fungal infections (PT Woo and DW Bruno, eds.), Vol 3, CAB Publishing, Wallingford, U.K., Pp 1-55.
Roberts RJ, MD Pearson. 2005. Infectious pancreatic necrosis in Atlantic salmon, Salmo salar L. J Fish Dis 28, 383-389.

Robertsen B. 2006. The interferon system of teleost fish. Fish Shellfish Immunol 2, 171-191.

Rodríguez S, JJ Borrego, SI Pérez-Prieto. 2003. Infectious pancreatic necrosis virus: biology, pathogenesis, and diagnostic methods. Adv Vir Res 62, 113-165.

Rodríguez Sain-Jean S, SI Pérez-Prieto. 2006. Interferon mediated antiviral activity against salmonid fish viruses in BF-2 and other cell lines. Vet Immunol Immunopat 110, 1-10.

Rønneseth A, E Pettersen, HI Wergeland. 2006. Neutrophils and B-cells in blood and head kidney of Atlantic salmon (Salmo salar L.) challenged with infectious pancreatic necrosis virus (IPNV). Fish Shellfish Immunol 20, 610-620.

Sano M, N Okamoto, H Fukuda, M Saneyoshi, T Sano. 1992. Virulence of IPNV is associated with the larger RNA segment (RNA segment A). J Fish Dis 15, 283-293.

Santi N, VN Vakharia, Ø Evensen. 2004. Identification of putative motifs involved in the virulence of infectious pancreatic necrosis virus. Virol 322, 31-40.

Santi N, H Song, VN Vakharia, Ø Evensen. 2005a. Infectious pancreatic necrosis virus VP5 is dispensable for virulence and persistence. J Virol 79, 9206-9216.

Santi N, A Sandtrø, H Sindre, H Song, JR Hong, B Thu, JL Wu, VN Vakharia, Ø Evensen. 2005b. Infectious pancreatic necrosis virus induces apoptosis in vitro and in vivo independent of VP5 expression. Virol 342, 13-25.

Smail DA, N Bain, DW Bruno, JA King, F Thompson, DJ Pendrey, S Morrice, CO Cunningham. 2006. Infectious pancreatic necrosis virus in Atlantic salmon, Salmo salar L., post-smolts in the Shetland Isles, Scotland: virus identification, histopathology, immunohistochemistry and genetic comparison with Scottish mainland isolates. J Fish Dis 29, 31-41.

Song H, N Santi, Ø Evensen, VN Vakharia. 2005. Molecular determinants of infectious pancreatic necrosis virus virulence and cell culture adaptation. J Virol 79, 10289-10299.

Stangeland S, S Høle, T Taksdal. 1996. Experimental induction of infectious pancreatic necrosis in Atlantic salmon, Salmo salar L., post- smolts. J Fish Dis 19, 323-327.

Villanueva RA, JL Galaz, JA Valdés, MM Jashés, AM Sandino. 2004. Genome assembly and particle maturation of the Birnavirus infectious pancreatic necrosis virus. J Virol 78, 13829- 13838.

Wolf K. 1988. Infectious pancreatic necrosis. En "Fish Viruses and Fish Diseases", Cornell Univ, Press, Ithaca, NY, Pp 115-157. 